\title{
Managing Marketing
}

Relationships

\section{Making Sure Everyone}

\section{Plays on the Team}

\author{
by Chekitan S. Dev,
}

James $R$. Brown, and

Dong-Jin Lee

\section{How oft the sight of means to do ill deeds \\ Makes deeds III done!}

—William Shakespeare, King John, Act 4, Scene 2
Chekitan S. Dev, Ph.D., is associate professor of strategic marketing at the School of Hotel Administration, Cornell University "csd5@cornell.edu». James R. Brown, D.B.A., is professor of marketing at the Pamplin College of Business, Virginia Polytechnic Institute and State University. Dong-Jin Lee, Ph.D., is assistant professor of marketing at the State University of New York at Binghamton. A more detailed technical version of this article was previously published in the Journal of Marketing. The authors acknowledge support for this study from the summer research programs of the Pamplin College of Business and the Cornell School of Hotel Administration; the two hotel companies they studied; and Reed Fisher, Shankar Ganesan, Janet E. Keith, Robert F Lusch, and Rajan Varadarajan.

C 2000, Cornell University 
When a firm behaves opportunistically it is seeking to increase its short-term, unilateral gains, perhaps even at the expense of its trading partner. Some such actions include hiding or misrepresenting financial results, overstating the need for trading-partner support (e.g., lowcost renovation loans), or neglecting obligations to the trading partner (e.g., hotel's commitment to promote the brand). As a result, opportunism by one party can erode the long-term gains potentially accruing to both parties in a relationship.

Because opportunism can be destructive to a business relationship, restraining opportunism is critical to enhancing performance and to increasing partners' satisfaction with the arrangement. ${ }^{1}$ After all, the prospect of increased gains is what motivates each party to join forces in creating a business relationship.

As noted by Stump and Heide, a number of mechanisms are available for managing opportunism among independently owned firms in a business relationship. ${ }^{2}$ Even before any contracts are signed, business operators should carefully select their partners, and they should design relationship agreements to discourage opportunistic behavior. Once the contract is signed, each party should monitor its partner's behavior to ensure that the partner is living up to its obligations. Another thing the partners can do after the contract is signed is to develop shared relational-exchange norms and values, which engender an atmosphere of mutual benefit,

\footnotetext{
${ }^{1}$ Jule B. Gassenheimer, David B. Baucus, and Melissa S. Baucus, "Cooperative Arrangements among Entrepreneurs: An Analysis of Opportunism and Communication in Franchise Structures," Journal of Business Research, Vol. 36, May 1996, pp. 67-79.

${ }^{2}$ Rodney L. Stump and Jan B. Heide,

"Controlling Supplier Opportunism in Industrial Relationships," Journal of Marketing Research, Vol. 33 (November 1996), pp. 431-441.
}

thereby mitigating opportunistic behavior. ${ }^{3}$ For example, with the shared norm of conflict harmonization, the partners attempt to settle their disputes so that both parties are satisfied, as opposed to taking a "winner vs. loser" approach to resolving their disagreements. An extreme way to attempt to ensure that a contract is upheld is for one company to buy the other. ${ }^{4}$ While ownership should forestall opportunistic behavior, things do not always work out that way, as we explain below.

For some time now researchers have recognized that a firm may employ a variety of mechanisms for governing transactions. ${ }^{5}$ In this research we focus on three specific mechanisms for mitigating opportunism: (1) ownership, (2) investment in transaction-specific assets, and (3) development of relationalexchange norms. We investigated the efficacy of each of those in managing opportunism individually and in combination.

By identifying the most effective of those three mechanisms (whether singly or in combination), managers should gain a better understanding of which governance mechanisms to use in effectively and efficiently managing opportunism in their business relationships. One goal of such control is to contain distribution costs. The twin benefits of lower costs are lower prices to business users and consumers and increased profitability for the partners.

\footnotetext{
${ }^{3}$ See: Jan B. Heide and George John, "Do Norms Matter in Marketing Relationships?," Journal of Marketing, Vol 56, April 1992,pp. 32-44; Ian R. Macneil, The New Social Contract (New Haven, CT: Yale University Press, 1980); and F. Robert Dwyer, Paul F. Schurr, and Sejo Oh, "Developing Buyer-Seller Relationships," Journal of Marketing, Vol. 51, April 1987, pp. 11-27.

${ }^{4}$ Oliver $\mathrm{E}$. Williamson, The Economic Institutions of Capitalism-Firms, Markets, Relational Contracting (New York: Free Press, 1985).

${ }^{5}$ Jeffrey L. Bradach and Robert G. Eccles,

"Price, Authority, and Trust: From Ideal Types to Plural Forms," Annual Review of Sociology, Vol. 15 (1989), pp. 97-118.
}

Some hotel GMs exhibit opportunistic behavior at the expense of the parent company, and mitigating such mischief is not an easy task. 
We begin with a brief discussion of opportunism in marketing channels and then describe three mechanisms for governing marketing channels drawn from the concepts of transaction-cost analysis and relational-exchange theory. Next, we describe an empirical test of hypotheses relating to channel governance and then discuss the results of this study, emphasizing how these governance mechanisms can be used for either preventing or constraining opportunism.

Our hypotheses are tested using relationships in the hotel industry between individual hotels and their brand headquarters. On the one hand, the corporate brand headquarters focuses on developing and maintaining the overall marketing program, including the brand identity. On the other hand, the managers at an individual hotel property may be less than assiduous in fostering that brand identity. The chief reason we chose this setting is that hotel chains use a variety of mechanisms to govern individual properties' operations. Among these mechanisms are corporate ownership of each hotel (e.g., Red Roof Inns), franchise agreements (e.g., Holiday Inn), owning transactionspecific assets (e.g., reservation systems), and relational exchange (e.g., Choice Hotels' use of regional sales reps to assist its franchised hotels in developing marketing programs and in implementing company-wide marketing programs). ${ }^{6}$

\footnotetext{
${ }^{6}$ For a fuller discussion of these and other mechanisms used to govern vertical relationships in the hotel industry, see: Chekitan S. Dev and James R. Brown, "Franchising and Other Operating Arrangements in the Lodging Industry: A Strategic Comparison," Hospitality Research Journal, Vol. 15 (1991), p. 25; Robert C. Lewis, Richard E. Chambers, and Harsha E. Chacko, Marketing Leadership in Hospitality: Foundations and Practices, Second Edition (New York: Van Nostrand Reinhold, 1995), pp. 650-680; and Mike Malley, "Getting the Most Value Out of Franchising," Hotel and Motel Management (supplement), May 5, 1997, pp. 31ff.
}

Opportunistic Behavior

Much of the conceptual framework regarding controlling opportunistic behavior is grounded in transaction-cost analysis. This approach provides a theoretical rationale for the operation of governance structures ranging from open markets (i.e., exchange among independent producers and distributors) to hierarchies, where many of the factors of production and distribution are owned in common. Franchising is in the midst of that range of governance structures because it shares characteristics with both markets and hierarchies.

The applicability of a particular governance mechanism depends on the relationship of the parties involved. ${ }^{7}$ For example, the governance mechanisms relating to fastfood franchises are well suited to ensuring that each operator, though independent, provides a uniform market offering. By contrast, mass merchandisers that integrate the wholesaling function use hierarchies to achieve economies of scale or economies of scope. Hierarchies also allow for benchmarking the performance of independent distributors (e.g., comparing franchised outlets with companyowned stores).

Opportunism refers to "a lack of candor or honesty in transactions, to include self-interest seeking with guile." 8 One important asset that a brand headquarters risks when hotels operate under its brand name, for instance, is the equity that it has built up in its brand. Opportunistic behavior can potentially erode the value of the brand. Such behavior can occur either before the business arrangement is established or during the course of a relationship.

\footnotetext{
${ }^{7}$ Jeffrey Bradach, "Using the Plural Form in the Management of Restaurant Chains," Administrative Science Quarterly, Vol. 42, June 1997, pp. $276-303$.

${ }^{8}$ Williamson, p. 9.
}

Opportunism before the fact (i.e., adverse selection) occurs when one firm disguises its true ability to perform the functions required of the exchange. Hotel operators use due diligence to prevent this form of opportunism. Franchise systems, for instance, carefully screen potential franchisees in an attempt to sign up only those firms that are likely to maintain the hotel chain's quality image. Franchisees, on the other hand, attempt to verify independently the franchisor's revenue and profit projections. Parties in a prospective management agreement also make similar due-diligence efforts before they sign a hotelmanagement contract.

Opportunism can also occur once the relationship has been launched. Examples of such opportunism include withholding or distorting information so as to "mislead, distort, obfuscate, or otherwise confuse," or shirking duties, as in the case of "not delivering the promised action and resources, and failing to do this on a fairly systematic and sustained basis." 10 Hotel chains protect themselves against franchisee opportunism in a number of ways, including attempting to establish a code of ethical operation and setting up a system of strict inspections.

\section{Mitigating Opportunism}

Following Heide, we view governance as "a multidimensional phenomenon which encompasses the initiation, termination, and ongoing relationship maintenance between a set of parties." 11 Governance mechanisms establish and structure exchange relationships, and, as Williamson notes, "governance structures differ in their capacities to respond effectively to disturbances

\footnotetext{
${ }^{9}$ Williamson, p. 47.

${ }^{10}$ Kenneth G. Hardy and Alan J. Magrath, "Dealing with Cheating in Distribution," European Journal of Marketing, Vol. 23 (1989), p. 123.

${ }^{11}$ Heide, p. 72.
} 
[i.e., opportunism]."12 Accordingly, we examine the efficacy of three different mechanisms for mitigating opportunism in hotel-marketing channels. As we said above, those mechanisms are (1) brand headquarters' ownership of the hotel, (2) investments made by the hotel in transaction-specific assets, and (3) relational-exchange norms developed between the hotel and its brand headquarters.

Ownership. A central tenet of transaction-cost analysis is that investments in transaction-specific assets are often best safeguarded through ownership..$^{13}$ Ownership enables the hotel-brand headquarters to manage its hotels' opportunistic tendencies in two ways. First, ownership offers the potential for a richer system of reward and punishment. Second, the organizational culture shared by headquarters and its hotels provides common norms and values that (should) align their interests. ${ }^{14}$

Ownership permits a firm to employ extensive monitoring and surveillance of its outlets. ${ }^{15}$ For example, brand headquarters has access to necessary records and may conduct whatever inspections and request those reports necessary to evaluate a particular hotel's outcomes. Furthermore, a vertically integrated firm can use more subtle rewards with employees (e.g., assignments to desirable hotels) and more extensive sanctions (e.g., suspensions with or without pay) than the company can apply to independent partners. ${ }^{16}$ Most telling,

\footnotetext{
${ }^{12}$ Williamson, pp. 56-57.

${ }^{13}$ See: Anderson, pp. 247-264; and George John and Barton A. Weitz, "Forward Integration into Distribution: An Empirical Test of Transaction Cost Analysis," Journal of Law, Economics, and Organization, Vol. 4, Fall 1988, pp. 337-355.

${ }^{14}$ Rindfleisch and Heide, p. 32.

${ }^{15}$ Oliver E. Williamson, Markets and Hierarchies: Analysis and Anti-Trust Implications (New York: Free Press, 1975).

${ }^{16}$ Erin Anderson and Barton A. Weitz,

"Make-or-Buy Decisions: Vertical Integration and Marketing Productivity," Sloan Management Review, Vol. 27, Spring 1986, pp. 3-19.
}

ownership weakens the parties' incentive to behave opportunistically because no individual part of the company generally can make an opportunistic gain without ultimately hurting itself (as part of the company). ${ }^{17}$

Second, under common ownership, the brand headquarters and its hotels are more likely to share a similar organizational culture and, thus, also share a consistent set of norms and values. Through this common set of norms and values, the hotel's objectives become more closely aligned with those of the brand headquarters. When the hotel's objectives are aligned with its brand headquarters, the hotel managers' incentive to behave opportunistically is reduced. To act with opportunism would subvert their own goal achievement.

These two characteristics of brand headquarters' hotel ownership should lead to the same resultnamely, reduced opportunism on the part of individual hotels. Therefore, our first hypothesis is that a hotel's opportunism will be reduced where brand headquarters has full ownership of the hotel, as compared to situations where the hotel is independently owned.

Transaction-specific assets. Transaction-specific assets are items that have little or no value outside of the exchange relationship. ${ }^{18}$ Such assets include specialized equipment and facilities, as well as specialized training and experience. ${ }^{19}$ For example, chain-affiliated hotels often invest in specific physical assets (e.g., furnishings, supplies, and signs) and idiosyncratic intangible assets (e.g., information systems, reservations

\footnotetext{
${ }^{17}$ Williamson (1985), p. 45.

${ }^{18}$ Williamson (1985), p. 55; Ritu Lohita, Charles M. Brooks, and Robert E. Krapfel, "What Constitutes a Transaction-specific Asset? An Examination of the Dimensions and Types," Journal of Business Research, Vol. 30, July 1994, p. 265.

${ }^{19}$ Anderson and Weitz, pp. 3-19.
}

We were surprised to find that

opportunism was not reduced

among company-owned hotels,

relative to independently

owned chain properties. 


\section{Questionnaire Items for the Multi-item Construct Measures}

\section{Hotel opportunistic behavior (HOPPRT)}

- We have always provided headquarters with a completely truthful picture of our business. (reversed)*

- We always carry out the duties of our relationship even if headquarters does not check up on us. (reversed)*

- We have sometimes promised headquarters that we would do things, even though we actually had no intention of following through."

- In terms of headquarters, we believe that it is OK to do anything within our means that will help further our hotel's interests. *

- To get the necessary support from headquarters, we sometimes mask the true nature of our needs.

- To get the needed support from headquarters, we sometimes overstate the difficulties our hotel faces.

- In order to maintain our goals (i.e., profitability, sales revenue, or market share), we occasionally find it necessary to neglect some of our obligations to headquarters.

- Regardless of its impact on our business (i.e., profitability, sales volume, or market share), we always conscientiously perform the duties of marketing this brand.

(reversed)

- Sometimes we have had to alter the facts slightly in order to get what we need from headquarters.

- On occasion, my hotel has had to lie to headquarters about certain things in order to protect our interests.

\section{Hotel Investment in transaction-specific assets (HTSA)}

- The systems and procedures we use with this brand could not be used for any other hotel brand without major changes.*

- To market our services under this brand, we have had specialized training that we couldn't use with another brand."

- Our hotel has spent a lot of time and effort to develop a strong customer base for this particular brand.

- The systems and procedures we use to sell hotel services are tailored for this brand.

- We have spent a lot of time and effort learning special selling techniques for this hotel brand.

- If we switched to a competitive brand, we would lose a lot of the investment we've made in marketing our services.

\section{Hotel's perceptions of relational} exchange (HRELATE)

- We expect our relationship with headquarters to last a long time.

- Both my hotel and headquarters consider the preservation of our relationship to be important.

- My hotel and headquarters are committed to the preservation of a good working relationship.

- Both my hotel and headquarters think it is important to continue our relationship." - Both my hotel and headquarters work hard at cultivating a good working relationship.

- Our relationship with headquarters does not go beyond us remitting their share of our sales revenue (or profits), negotiating room availability for the reservations system, and conforming to quality standards. (reversed) ${ }^{\star}$

- Even though our relationship with headquarters is not complex, we are still uncertain about who does what. (reversed)

- Our two organizations have well-formed expectations of each other which go beyond buying and selling products and services.

- Our relationship with headquarters has led to complex expectations, on the part of both organizations, over all kinds of issues."

- Even though our relationship with headquarters is extremely complicated, both parties have clear expectations as to the role each performs.

- There are standard procedures for resolving disputes between my hotel and headquarters that do not involve third-party intervention.

- My hotel and headquarters are very conscientious, responsive, and resourceful in maintaining a cooperative relationship.

- Both parties try to resolve any disagreements that arise between us in good faith.

- The high level of mutual trust between my hotel and headquarters enables us to settle our disagreements to everyone's satisfaction."

- Both my hotel and headquarters are generally able to resolve disagreements to both parties' satisfaction.
Note: All scale items are anchored by " 1 " (strongly disagree) or " 7 " (strongly agree).
* Starred items were deleted from further analysis. systems, and management procedures) that cannot easily be used if the hotel were to transfer to another chain.

Businesses invest in transactionspecific assets for at least three reasons. One reason is that such assets are more efficient and effective than generalized assets in accomplishing business objectives. For example, by investing in particular signs or computer software and by giving employees specialized training, a hotel can appeal more effectively to its target market and operate more efficiently in serving that market. A second reason for parties to invest in transaction-specific assets is to signal their honorable intentions with respect to their trading relationship. ${ }^{20}$ A third reason is that such investments may be required as a condition of exchange, beyond the purposes of effectiveness and efficiency. In this instance, transaction-specific assets can be required essentially as performance bonds to be forfeited if a firm is detected as behaving opportunistically.

Common to all three motives for investing in transaction-specific assets and explicit in the performancebonding motive is the potential for economic loss. Thus, regardless of its motives for investing in transactionspecific assets, if a relationship is terminated a firm can potentially lose those assets' full value (e.g., the value of a franchisee's building constructed on land leased from the franchisor), its nonsalvageable value (e.g., brand-specific knowledge that cannot be redeployed to other exchange relationships), and the future income stream generated by the assets (e.g., a hotel's traffic generated by its chain's reservation system). ${ }^{21}$

\footnotetext{
${ }^{20}$ Debi Pradad Mishra, Jan B. Heide, and Stanton G. Cort, "Information Asymmetry and Levels of Agency Relationships," Journal of Marketing Research, Vol. 35, August 1998, pp. 277-295.

${ }^{21}$ Paul Rubin, Managing Business Transactions (New York: The Free Press, 1990).
} 
Given that a firm's opportunistic behavior may be grounds for terminating a business relationship, several researchers have posited that the risk of forfeiting those idiosyncratic investments restrains hotel malfeasance. ${ }^{22}$ Thus, our second hypothesis is as follows: The hotel's opportunism will be reduced the more the hotel has invested in transaction-specific assets of its own.

Relational exchange. Relationships among firms can be characterized by exchange norms, such as role integrity, mutuality, solidarity, flexibility, information exchange, harmonious conflict resolution, and a long-term orientation..$^{23}$ Shared norms are characteristic of relational exchange, which is the final mechanism that we investigate for managing opportunism. Some of the common components of relational exchange are defined below.

Relationship preservation is the extent to which channel members: (a) view their relationship as distinct from a series of discrete transactions, (b) see the relationship important in and of itself, and (c) wish to preserve that relationship. ${ }^{24}$ Role integrity entails channel members' expectations for needed future roles and suggests that roles expand to "cover a multitude of issues not directly related to any particular transaction." 25 This contractual norm ensures the stability necessary for exchange relationships

\footnotetext{
${ }^{22}$ Among them: Stump and Heide, pp. 431-441.

${ }^{23}$ See: Patrick J. Kaufmann and Louis W. Stern, "Relational Exchange Norms, Perceptions of Unfairness, and Retained Hostility in Commercial Litigation," Journal of Conflict Resolution, Vol. 32 (1988), pp. 534-552; Patrick J. Kaufmann and Rajiv P. Dant, "The Dimensions of Commercial Exchange," Marketing Letters, May 1992, pp. 171-185; and Shankar Ganesan, "Determinants of Long-term Orientation in Buyer-Seller Relationships," Journal of Marketing, Vol. 58, April 1994, pp. 1-19.

${ }^{24}$ See: Macneil, op. cit.; and Kaufmann and Stern, pp. 534-552.

${ }^{25}$ Kaufmann and Stern, p. 536.
}

to deepen. ${ }^{26}$ The norm of harmonization of relational conflict refers to the extent to which channel members achieve mutually satisfying resolution of their conflicts. ${ }^{27}$ Because exchange norms are indicative of a construct dubbed relationalism, ${ }^{28}$ we view the extent of relational exchange in a marketing channel as the degree to which the norms of role integrity, preservation of the relationship, and harmonization of relational conflict characterize that channel.

Thus, relational exchange limits opportunism through the sharing of common norms and values. By subscribing to a relationshippreservation norm, the exchange partners see the relationship as ongoing and mutually beneficial, and they will, therefore, refrain from taking actions that jeopardize the relationship. In summary, the norms engendered in relational exchange provide another way that channel members safeguard themselves from opportunistic behavior. ${ }^{29}$

Based on those arguments, we hypothesize that: The hotel's opportunism will be reduced the more the hotel perceives a relational exchange with its brand headquarters.

We also tested for any interactions among the three possible

\footnotetext{
${ }^{26}$ See: Rajiv P. Dant and Patrick L. Schul, "Conflict Resolution Processes in Contractual Channels of Distribution," Journal of Marketing, Vol. 56, January 1992, p. 43; and Kaufmann and Dant, pp. 171-185.

${ }^{27}$ Macneil, op. cit.

${ }^{28}$ See:Thomas G. Noordwier, George John, and John R. Nevin, "Performance Outcomes of Purchasing Arrangements in Industrial BuyerVendor Relationships," Joumal of Marketing, Vol. 54, October 1990, pp. 80-93; and Heide and John, pp. 32-44.

${ }^{29}$ See:Victor P. Goldberg, "Relational Exchange," American Behavioral Scientist, Vol. 23 (1980), pp. 337-352; Paul L. Joskow, "Contract Duration and Relationship-specific Investments: Empirical Evidence from Coal Markets," American Economic Review, Vol. 77, No. 1 (1987), pp. 168-185; Jan B. Heide and George John, "Alliances in Industrial Purchasing: The Determinants of Joint Action in Buyer-Supplier Relationships," Journal of Marketing Research, Vol. 27,

February 1990, pp. 24-36; and Ganesan, pp. 1-19.
}

methods of controlling opportunism. That is, for example, whether ownership combined with a relational exchange had even more influence than ownership alone.

\section{On Good Behavior}

We tested our hypotheses by examining the relationship between individual hotels and their brand headquarters in two large hotel chains doing business in North America. We selected these two companies because each has both company-owned properties and franchised units. The questionnaire that we sent was pretested with a group of over 30 hotel GMs enrolled in a university executivedevelopment program. We also asked senior managers in both hotel chains to review the questions to ensure their relevance.

We surveyed hotel general managers to gather our data, because our pretest determined that the hotel's GM was the person within the hotel best qualified to report on the hotel's relationship with its brand headquarters. The two hotel chains provided names of GMs and their hotel addresses so that we could send them a questionnaire. We sent the questionnaire to 1,736 hotel general managers, but some were undeliverable or their hotels had switched brand affiliation. That left a pool of 1,650 potential respondents.

To increase the response rate, we included a cover letter in support of the research from the hotel company's chief operating officer, and we assured the participants that all responses were confidential. Thus, we present only aggregate results here. We also offered each participant an executive summary of the study as an inducement to participate. Finally, we sent follow-up letters to managers who did not respond within four weeks of the initial mailing. With all this, we received completed responses from 


\section{Exhibit 1}

\section{Variable intercorrelations, means, and standard deviations $(n=368)$}

\begin{tabular}{|c|c|c|c|c|c|c|c|c|c|c|}
\hline \multirow[b]{2}{*}{ Variables } & \multicolumn{6}{|c|}{ Factors (see key below) } & & & & \\
\hline & 1 & 2 & 3 & 4 & 5 & 6 & 7 & 8 & 9 & 10 \\
\hline 1. HOPPRT & 1.000 & & & & & & & & & \\
\hline 2. OWNS & 0.035 & 1.000 & & & & & & & & \\
\hline 3. HTSA & -0.021 & 0.056 & 1.000 & & & & & & & \\
\hline 4. HRELATE & -0.316 & 0.055 & 0.359 & 1.000 & & & & & & \\
\hline 5. OWNS $\times$ HTSA & 0.008 & 0.208 & 0.246 & 0.132 & 1.000 & & & & & \\
\hline 6. OWNS $\times$ HRELATE & -0.043 & 0.145 & 0.097 & 0.334 & 0.392 & 1.000 & & & & \\
\hline 7. HTSA $\times$ HRELATE & -0.012 & -0.018 & 0.110 & -0.237 & -0.020 & -0.097 & 1.000 & & & \\
\hline 8. OWNS $\times$ HTSA $\times$ HRELATE & 0.052 & 0.288 & 0.003 & -0.087 & 0.007 & -0.267 & 0.276 & 1.000 & & \\
\hline 9. TOTEMP & -0.051 & 0.173 & 0.037 & 0.056 & 0.039 & 0.113 & 0.059 & 0.028 & 1.000 & \\
\hline 10. FIRM_B & -0.040 & 0.070 & -0.130 & -0.129 & 0.080 & -0.004 & 0.136 & 0.101 & 0.476 & 1.000 \\
\hline Mean & 2.232 & 0.106 & 4.315 & 5.413 & 0.025 & 0.017 & 0.511 & 0.046 & 148.361 & 0.223 \\
\hline Standard Deviation & 1.051 & 0.308 & 1.406 & 1.015 & 0.344 & 0.338 & 1.509 & 0.463 & 149.741 & 0.417 \\
\hline
\end{tabular}

Key to factors: (1) Opportunism, (2) Ownership (company or independent), (3) Transaction-specific assets (intangibles, such as reservationsystem software and training), (4) Extent of relational exchange (common interests, norms, and values), (5) Interaction of ownership and transaction-specific assets, (6) Interaction of ownership and relational exchange, (7) Interaction of transaction-specific assets and relational exchange, (8) Interaction of ownership, transaction-specific assets, and relational exchange, (9) Hotel size, and (10) Company affiliation.

\section{Exhibit 2 \\ Regression estimates for governance mechanisms on hotel opportunism}

\begin{tabular}{llc|c|c|c|c} 
& & \multicolumn{2}{c}{ Factor Estimate } & Std. & & 1-tailed \\
Factor* & Variable & Unstd. & Std. & Error & t-value & $p$ \\
\hline $\mathbf{b}_{0}$ & Intercept Term & 2.304 & 0.000 & 0.075 & 30.716 & 0.000 \\
$\mathbf{b}_{1}$ & TOTEMP & 0.000 & -0.011 & 0.000 & -0.193 & 0.424 \\
\hline $\mathbf{b}_{2}$ & FIRM_B & -0.159 & -0.063 & 0.147 & -1.085 & 0.139 \\
$\mathbf{b}_{3}$ & OWNS & 0.070 & 0.021 & 0.185 & 0.379 & 0.352 \\
\hline $\mathbf{b}_{4}$ & HTSA & 0.097 & 0.130 & 0.042 & 2.294 & 0.011 \\
$\mathbf{b}_{5}$ & HRELATE & -0.441 & -0.426 & 0.061 & -7.284 & 0.000 \\
\hline $\mathbf{b}_{6}$ & OWNS $\times$ HTSA & -0.021 & -0.007 & 0.173 & -0.120 & 0.452 \\
$\mathbf{b}_{7}$ & OWNS $\times$ HRELATE & 0.296 & 0.095 & 0.187 & 1.583 & 0.057 \\
\hline $\mathbf{b}_{8}$ & HTSA $\times$ HRELATE & -0.090 & -0.129 & 0.038 & -2.365 & 0.009 \\
$\mathbf{b}_{9}$ & OWNS $\times$ HTSA $\times$ HRELATE & 0.174 & 0.076 & 0.129 & 1.342 & 0.090
\end{tabular}

Note: Regression statistics for the equation are as follows:

$$
\mathrm{R}^{2}=0.137 ; \mathrm{F}=6.324 ; \mathrm{df}=9.358 ; p<0.01 \text {. }
$$

*Key to factors: $\left(b_{1}\right)$ Hotel size, $\left(b_{2}\right)$ Company affiliation, $\left(b_{3}\right)$ Ownership,

$\left(b_{4}\right)$ Transaction-specific assets, $\left(b_{5}\right)$ Extent of relational exchange,

$\left(b_{6}\right)$ Interaction of ownership and transaction-specific assets,

$\left(b_{7}\right)$ Interaction of ownership and relational exchange,

$\left(b_{8}\right)$ Interaction of transaction-specific assets and relational exchange,

$\left(b_{9}\right)$ Interaction of ownership, transaction-specific assets, and relational exchange.
368 general managers (a response rate of 22.3 percent).

We checked our sample for nonresponse bias in two ways. First, we telephoned 50 randomly drawn nonrespondents to ask a series of descriptive questions along with a random selection of items from the questionnaire. No significant differences on those questions $(p>0.10)$ were found between the original respondents and our sample of 50 nonresponding GMs. We also noted that the profile of those who did not respond closely matched the company-wide profiles provided by the two brands' headquarters. As a separate matter, we looked at the timing of responses but could find no significant differences in the variable means between early responders and late responders.

\section{Measuring Opportunism}

We tested opportunism (the guileful seeking of self interest) by adapting 
ten items developed by previous researchers who also investigated opportunism. ${ }^{30}$

For our purposes, transactionspecific assets mostly involve the intangible aspects of hotel operations (e.g., time and effort spent in developing a customer base for the brand; systems and procedures tailored to the brand). Most tangible assets (e.g., furnishings, equipment, and supplies), on the other hand, can be used in other relationships. Consequently, we developed six items to measure the hotel's investment in idiosyncratic intangible assets (see the box on page 14). ${ }^{31}$

As noted earlier, we viewed the construct of relational exchange as being reflected by role integrity, preservation of the relationship, and harmonization of conflict. Accordingly, hotel general managers were asked to rate 15 items, based on those developed by Kaufmann and Dant, for measuring these three aspects of the hotels' relationships. ${ }^{32}$

We used several statistical tests, including confirmatory factor analysis, to evaluate whether the questions were actually testing for the intended constructs. Among other tests, we examined a goodness-offit index, a comparative-fit index, and nonnormed and normed incremental-fit indices. Values for

\footnotetext{
${ }^{30}$ For example, see: John, pp. 278-288; F. Robert Dwyer and Sejo Oh, "Output Sector Munificence Effects on the Internal Political Economy of Marketing Channels," Journal of Marketing Research, Vol. 24, November 1987, pp. 347-358; Anderson, pp. 247-264; and Keith G. Provan and Steven J. Skinner, "Interorganizational Dependence and Control as Predictors of Opportunism in Dealer-Seller Relations, Academy of Management Journal, Vol. 32, March 1989, pp. 202-212.

${ }^{31}$ Based on: Jan B. Heide and George John, "The Role of Dependence Balancing in Safeguarding Transaction-specific Assets in Conventional Channels,"Journal of Marketing, Vol. 52, January 1988 , pp. $20-35$; Heide and John, pp. 2436; and Saul Klein, Gary L. Frazier, and Victor J. Roth, "A Transaction-cost-analysis Model of Channel Integration in International Markets," Journal of Marketing Research, Vol. 27, May 1990, pp. $196-208$.

${ }^{32}$ Kaufmann and Dant, pp. 171-185.
}

all of these indices exceeded their generally accepted thresholds of 0.90 for adequate model fit.

All factor loadings were statistically significant and roughly equal in magnitude. The composite reliability coefficient for each of these three multi-item constructs exceeded the 0.60 threshold necessary for measurement reliability. ${ }^{33}$ In addition, the average variance extracted for each construct surpasses its 0.50 threshold for adequate fit. ${ }^{34}$ The largest between-factor correlation was -0.45 , which was significantly less than unity; this finding provides evidence of the discriminant validity of these measures. ${ }^{35}$ All of these tests give us confidence that behavioral measures are indeed reliable, unidimensional, and valid.

Ownership. We asked each hotel's general manager to indicate on a nominal scale whether the hotel was 100 -percent chain owned, 100-percent independently owned, or had shared ownership. We eliminated the shared-ownership properties because there were so few of them (27 hotels). Our analysis compared the 39 hotels that were $100-$ percent chain owned and the 329 properties that were 100 -percent independently owned.

Control variables. Since other factors might account for a substantial amount of the variance in hotel opportunism, we included two control variables. Given that the sample consisted of hotels representing two different brands in the lodging industry, differences in the operation of these chains might affect the degree of relational norms and level

\footnotetext{
${ }^{33}$ Richard P. Bagozzi and Youjae Yi, "On the Evaluation of Structural Equation Models," Journal of the Academy of Marketing Science, Vol. 16, Spring 1988, p. 80 .

${ }^{34}$ Ibid.

${ }^{35}$ Lynn W. Phillips, "Assessing Measurement Error in Key Informant Reports: A Methodological Note on Organizational Analysis in Marketing," Journal of Marketing Research, Vol. 18, November 1981, pp. 395-415.
}

of opportunism they experience. For this reason, each hotel in the sample was coded according to which chain it represented. We also wanted to control for the size of the hotel, believing that large hotels may experience different relationships with their brand headquarters than small ones.

\section{Analytical Procedure}

We summarized our hypotheses in a regression equation. In addition to the control variables (for size and chain affiliation), the equation included a dummy variable for ownership (that is, owns or doesn't own), plus seven terms, one for each of the three main hypotheses, one for each dual combination of ownership, transaction-specific assets, and relationship, and one for all three of those combined. ${ }^{36}$ We estimated this equation using the moderatedregression approach. ${ }^{37}$ We limited multicollinearity between the interaction terms and their components by centering the numerical scales for transaction-specific assets and relationships on their respective mean points. As shown in Exhibit 1, multicollinearity was low, as the largest amount of variance shared between any two variables is 22.7 percent.

Exhibit 2 reports the results of this moderated, ordinary-leastsquare regression analysis. The estimated equation explains a relatively small 13.7 percent of the variation in hotel opportunism. Neither the size of the hotel nor its brand affilia-

\footnotetext{
${ }^{36}$ The regression equation is as follows: HOPPRT $=b_{0}+b_{1}$ TOTEMP $+b_{2}$ FIRM_B + $b_{3}$ OWNS $+b_{4}$ HTSA $+b_{5}$ HRELATE $+b_{6}$ (OWNS $\times$ HTSA) $+b_{7}$ (OWNS $\times$ HRELATE) $+b_{8}\left(\right.$ HTSA $\times$ HRELATE) $+b_{9}$ (OWNS $\times$ HTSA $\times$ HRELATE) + e.

${ }^{37}$ Detailed by James Jaccard, Robert Turrisi, and Choi K. Wan, Interaction Effects in Multiple Regression (Newbury Park, CA: Sage Publishing, 1990); and Leona S. Aiken and Stephen G. West, Multiple Regression: Testing and Interpreting Interactions (Newbury Park, CA: Sage Publishing, 1991).
} 


\section{Exhibit 3 \\ Effects of governance mechanisms on opportunism}

\begin{tabular}{|c|c|c|c|}
\hline Governance mechanism & $\begin{array}{c}\text { Estimated effect } \\
\text { on hotel } \\
\text { opportunism }\end{array}$ & $\begin{array}{l}\text { standard } \\
\text { error }\end{array}$ & $t$-value \\
\hline Brand headquarters' ownership of hotel & 0.047 & 0.334 & 0.140 \\
\hline Hotel investment in transaction-specific assets & 0.188 & 0.064 & 2.954 \\
\hline $\begin{array}{l}\text { Relational exchange between hotel and its } \\
\text { brand headquarters }\end{array}$ & -0.315 & 0.068 & 4.609 \\
\hline
\end{tabular}

tion was statistically significant, so we could eliminate those factors as influencing a hotel's opportunistic behavior.

\section{Differentiating Governance Mechanisms}

All of the hypotheses focus on the relationship between hotel opportunism and the mechanisms used to govern the relationship between a hotel and brand headquarters. Because we included interaction terms to represent combinations of governance mechanisms, we had to untangle those interaction effects. This is done by differentiating the regression equation with respect to each governance mechanism (signified by the letter $\partial$ ). We did this for each factor in turn, at the same time setting the values for the other two factors at one standard deviation below the mean. ${ }^{38}$

Ownership effect. We first tested the effect of ownership, recalling in Hypothesis 1 that brand headquarters' equity in the hotel will limit the hotel's opportunistic behavior. We therefore expected the term of the derivative of the opportunism factor with respect to the ownership factor to be negative. Instead, we received a positive value for this factor (expressed as 2HOPPRT $/$ OOWNS $=0.047$ ). Thus, when brand headquarters

\footnotetext{
${ }^{38}$ Jaccard, Turrisi, and Wan, op. cit.
}

owns the hotel, the hotel may be slightly more likely to behave opportunistically. This finding was not significant, however, and we conclude that, contrary to our first hyership of the hotel has no significant effect on hotel opportunism. Remember, though, that we assumed low levels of transaction-specific assets and relational exchange.

Special assets. We hypothesized that the more the hotel has invested in transaction-specific assets, the less likely it is to engage in opportunistic behavior. Our procedure for testing this hypothesis was similar to that of the first hypothesis. We isolated hotel-specific assets by assuming that the hotel would be independently owned and that the extent of relational exchange between the hotel and its headquarters was minimal. As reported in Exhibit 3 , this analysis shows that the derivative of opportunism with respect to transaction-specific assets

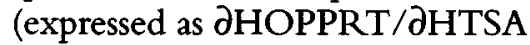
$=0.188)$ is positive and statistically significant $(p<0.01)$. Contrary to our hypothesis, this outcome implies that the more the hotel has invested in transaction-specific assets, the more it will behave opportunistically. This finding indicates that somehow the hotel's idiosyncratic assets exacerbate its opportunistic behavior. pothesis, brand headquarters' own-
Relational exchange. In contrast, we found that the use of relational exchange as a governance mechanism mitigates a hotel's opportunistic tendencies. The derivative of opportunism with respect to the relationship returned a negative value that was significant (expressed as $\partial \mathrm{HOPPRT} / \partial \mathrm{HRELATE}=$ $-0.315, p<0.01$ ). Again, we arrived at this conclusion by assuming independent hotel ownership and low levels of hotel investment in idiosyncratic assets. Those results are consistent with our hypothesis regarding relational exchange.

\section{Combining Govemance Mechanisms}

In examining the simultaneous effect of the three governance mechanisms, we follow the original premise of transaction-cost analysis in assuming that ownership is the key governance alternative to the discipline of the marketplace. ${ }^{39}$ Accordingly, we adjusted the equation to reflect the assumption that the hotel's idiosyncratic investments and the extent that it perceives relational exchange with its brand headquarters moderate the effects of brand headquarters' ownership on hotel opportunism. Because the use of transaction-specific assets as a governance mechanism is also rooted in transaction-cost analysis, we assume that a firm relationship moderates any linkage between opportunism and transaction-specific assets.

Ownership and assets. We found a moderate effect on opportunism resulting from a combination of a brand's ownership of a hotel and the hotel's investment in transaction-specific assets. The effect, however, was not significant, so we had to reject any hypothesis suggesting that the hotel's investment in specialized assets coupled

\footnotetext{
${ }^{39}$ See:Williamson (1975), op. cit.; and Rindfleisch and Heide, pp. 30-54.
} 
with headquarters' ownership of the hotel will reduce hotel opportunism

Ownership and relations. We came to a similar conclusion for the hypothesis that higher degrees of relational exchange will intensify the effect of headquarters' ownership of the hotel in lessening the hotel's opportunistic behavior. Increasing levels of relational exchange along with brand headquarters' ownership heightened, rather than reduced, hotel opportunism. The differences among those effects were not statistically significant, however.

Assets and relationship. We also had to reject the idea that a decline in a hotel's opportunistic behavior can be accelerated by a combination of increasing idiosyncratic investments and a greater relational exchange with its brand headquarters. Our results were consistent with the spirit of this hypothesis, but we found that changes in the level of relational exchange did not affect the relationship between opportunism and transactionspecific assets. Similarly, a combination of all three factors did not have a signficantly greater effect on opportunism than did each one independently. In fact, increasing both hotel asset investment and relational exchange from moderate to high levels had a significant impact on the efficacy of the ownership governance mechanism $(p>0.01)$, but in the wrong direction. That is, this combination exacerbated rather than mitigated hotel opportunism.

\section{A Relational-exchange Perspective}

Because transaction-cost analysis has played a huge role in the study of marketing-channel governance, we focused on the role of relational exchange in moderating the effects of transaction-cost governance mechanisms (that is, the effects of ownership and idiosyncratic investments) on opportunistic behavior.
In this section, we turn that analysis around and look at how transactioncost mechanisms moderate the impact of relational exchange on hotel opportunism. Instead of focusing on a comparison of the derivatives of opportunism and ownership or opportunism and assets, we instead evaluate the derivative of opportunism with respect to the relationship

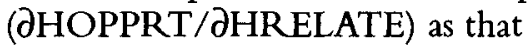
term is mitigated by the other factors, ownership and investment in specific assets.

We found, for instance, that ownership has a significant influence on the effect of relational exchange on hotel opportunism and specifically that brand ownership reduces opportunism in the presence of a good relationship. Assuming independent hotel ownership, the effect of increasing investment in specialized assets is to increase the influence of relational exchange in supressing opportunism $(p<0.01)$.

Ostensibly, our investigation of the impact of the simultaneous use of these governance mechanisms produced contradictory findings. Some of our results were supportive of the hypotheses, while others were not. Although an analysis using the transaction-cost approach generally did not support the hypotheses, application of a relationalexchange perspective did. Where relational exchange is emphasized (either singly or in combination with idiosyncratic investments), hotel opportunism decreases. Where either ownership or investments in specialized assets are stressed, hotel opportunism increases. We explore possible reasons for these results in the following section.

\section{Managerial Implications}

The strongest finding coming from this analysis is that a chain's managers should focus their efforts on building an effective relationship with the GMs of their affiliated hotels. A strong relationship is the only governance mechanism (whether by itself or in combination with others) that placed any significant limitation on hotel opportunism among hotels in our sample. On the other hand, simply owning the hotel has no significant effect on its opportunistic actions, even when combined with the other governing mechanisms. Contrary to the predictions of transaction-cost theory, we found that a hotel's opportunism can actually increase as its investment in specialized assets also increases.

Those results suggest that if brand headquarters aggressively exerts its rights of ownership, it could well exacerbate opportunism. One explanation for this is that ownership pressure and sanctions may provoke the hotels' general managers into exerting their independence-thus "producing the very behavior they [the sanctions] were intended to discourage." ${ }^{40}$ Examples might be concealing important information, communicating invalid or misleading information, or intentionally neglecting agreed-upon duties. ${ }^{41}$ Moreover, the extrinsic rewards available through hotel ownership may crowd out the hotel manager's intrinsic motivation to be a team player, especially where norms of relational exchange are prevalent. ${ }^{42}$

\footnotetext{
${ }^{40}$ Maria Moschandreas, "The Role of Opportunism in Transaction Cost Analysis," Journal of Economic Issues, Vol. 31, March 1997, p. 47.

${ }^{41}$ See: Sumantra Ghoshal and Peter Moran, "Bad For Practice: A Critique of the Transaction Cost Theory," Academy of Management Review, Vol. 21 (1996), pp. 3-47; and Sridhar N. Ramaswami,

"Marketing Controls and Dysfunctional Employee Behaviors: A Test of Traditional and Contingency Theory Postulates," Journal of Marketing, Vol. 60, April 1996, pp. 105-120.

${ }^{42}$ Compare to: Bruno S. Frey, "Does Monitoring Increase Work Effort? The Rivalry with Trust and Loyalty," Economic Inquiry, Vol. 31, October 1993, p. 666.
} 
This may shift the hotel GM's perspective of brand headquarters from an orientation based on a mutual relationship to one involving calculation, making opportunism more likely if the GM sees an advantage in behaving with guile.

In contrast, the emphasis of relational exchange rests on building common norms and values. A strong relationship leads to a sense of identification between the hotel and its brand headquarters. The hotel manager believes that whatever harms brand headquarters damages the hotel, and vice versa. Our data showed that this effect persists even when relational exchange is used in conjunction with ownership or investment in specialized assets (strategies that don't work by themselves). Thus, it seems that top management should emphasize building strong relationships to reduce opportunistic behavior at affiliated hotels.

\section{Relations over Transactions}

The finding that brand headquarters' ownership of the hotel does little to limit the hotel's opportunism is not consistent with transaction-cost theory. The same can be said for our results regarding investments in transaction-specific assets. Again, traditional operational arguments for these investments (i.e., they are made for the purposes of efficient and effective operation) appear to outweigh transaction-cost arguments. One interpretation of the positive link between a hotel's investment in specialized assets and opportunism is that opportunistic behavior is one way in which the hotel can generate additional returns on such investments.

As we have already mentioned, hotel chains have motives other than mere governance for owning hotels and for having franchisees invest in such transaction-specific resources as reservation systems- and thus they may not regard such assets as governance mechanisms. Those motives include the operational consistency gained by ownership in fostering the hotel's critical role of maintaining and reinforcing the brand's image. However, because our sample comprised companyowned and franchised hotels from only two large hotel firms, additional research is needed to test the boundaries of our findings.

Another possible explanation for the failure of idiosyncratic assets as a control mechanism is that the hotel chains may have done a poor job of using those assets in governance. When monitoring or punishments are ineffectual, the threat of economic losses rooted in the hotel's asset investment has a limited ability to mitigate opportunism. Further research is needed to investigate the effectiveness with which brand headquarters monitors its hotels and sanctions them for opportunistic behavior.

Another matter of concern is that our regression equation explained less than 20 percent of the variation in hotel opportunistic behavior. Indeed, that may be a source of what appears to be backward results. A confounding variable could be missing from the equation-one that might change the influence of, say, transaction-specific assets on opportunistic behavior. This outcome suggests that we have omitted a number of constructs that might explain such behavior. Therefore, we recommend that future studies of opportunism include constructs such as fairness, ${ }^{43}$ conflict, ${ }^{44}$

\footnotetext{
${ }^{43}$ Nirmalya Kumar, Lisa K. Scheer, and JanBenedict E.M. Steenkamp, "The Effects of Supplier Fairness on Vulnerable Resellers," Journal of Marketing Research, Vol. 32, February 1995 , pp. 54-65.

${ }^{44}$ Louis W. Stern and Ronald H. Gorman, "Conflict in Distribution Channels: An Exploration," in Distribution Channels: Behavioral Dimensions, ed. Louis W. Stern (Boston: HoughtonMifflin, 1969), pp. 156-175.
}

exchange-partner replaceability, ${ }^{45}$ and exchange-partner investment in idiosyncratic assets. ${ }^{46}$

Our study contributes to the literature on marketing-channel governance in several key ways. One contribution is in the examination of whether the governance mechanisms interact. To our knowledge, this is the first study to examine the interaction-or lack thereof-among these governance mechanisms. More important, our results emphasize the effectiveness of relational exchange as a "stand alone" mechanism for limiting opportunism. This finding reinforces the research of Gundlach, Achrol, and Mentzer, who found commitment to be a critical factor in limiting opportunism. ${ }^{47}$

Finally, our results reveal that relational exchange plays a central role in the operation of ownership and asset investment as governance mechanisms. The most effective governance mechanisms that we uncovered were the combination of ownership with relational exchange and asset investment with relational exchange.

Perhaps the most intriguing outcome is that the mechanisms for governance described in transaction-cost analysis seem to be effective for hotels only in the context of relational exchange. That is a departure from much of the channel-governance literature. This result leads us to suggest that the extent of relational exchange between channel partners is an important factor that must be considered before offering prescriptions based purely on transaction-cost analysis. $\mathbf{C Q}$

\footnotetext{
${ }^{45}$ Robert A. Ping, Jr., "The Effects of Satisfaction and Structural Constraints on Retailer Exiting, Voice, Loyalty, Opportunism, and Neglect," Journal of Retailing, Vol. 69, Fall 1993, pp. 320-352.

${ }^{46}$ Rindfleisch and Heide, pp. 30-54.

${ }^{47}$ Gundlach, Achrol, and Mentzer, pp. 78-92.
} 